\title{
Quality of strawberry grown in Brazilian tropical humid conditions for breeding programs
}

\author{
Amanda Goncalves Guimarães ${ }^{1, \star}$, Valter Carvalho Andrade Júnior ${ }^{2}$, Alcinei Mistico Azevedo ${ }^{3}$, \\ Tiago Jesus Guedes ${ }^{2}$ and Nísia Andrade Villela Dessimoni Pinto ${ }^{2}$ \\ 1 Universidade Estadual do Norte Fluminense Darcy Ribeiro, Campos dos Goytacazes, RJ Brazil \\ 2 Universidade Federal dos Vales do Jequitinhonha e Mucuri, MG, Brazil \\ 3 Universidade Federal de Viçosa, MG, Brazil
}

Received 12 May 2015 - Accepted 10 February 2016

\begin{abstract}
Introduction. The preliminary study of the post-harvest quality of the fruit from strawberry cultivars in a new growing region is necessary for both farmers and consumers. The objective of the present study was to evaluate strawberry cultivars at different harvest times with regard to fruit quality aiming at the selection of possible parents for breeding programs for cultivation in the tropical humid conditions of the city Datas, in Minas Gerais State (Brazil), and in other regions with similar soil-climatic conditions. Materials and methods. The strawberry fields were cultivated on the Mape Frutas Farm, located in the city of Datas-MG. Eight cultivars ('Aromas', 'Camarosa', 'Campinas', 'Diamante', 'Dover', 'Festival', 'Oso Grande', and 'Toyonoka') were assessed in a randomized block design with a split-plot in time. Four replicates and three harvest times (June, August, and October 2012) were evaluated. Fruit from the different cultivars were analyzed for their physicochemical and antioxidant properties. Results and discussion. There was a genetic variability and the predominance of genetic factors over environmental effects for the evaluated traits. Fruits harvested at the end of the crop cycle (October) had the highest levels of total reducing sugars, vitamin C, phenols, anthocyanins, carotenoids, soluble solids, and total antioxidant activity. Cultivars Camarosa, Festival, and Toyonoka showed better fruit quality. Conclusion. Based on the genetic dissimilarity and fruit quality, the cross between 'Toyonoka' and 'Camarosa' or 'Festival' is indicated for the genetic improvement of strawberry in the region and other places with similar soil-climatic conditions.
\end{abstract}

Keywords: Brazil / strawberry / Fragaria $\times$ ananassa / plant breeding / fruit quality / genetic trait / nutritional value

\begin{abstract}
Résumé - Qualité des fraises cultivées dans les conditions tropicales humides du Brésil pour les programmes de sélection. Introduction. L'étude préliminaire de la qualité post-récolte des fruits du fraisier dans une nouvelle région de culture est une étape indispensable tant pour les agriculteurs que pour les consommateurs. L'objectif de la présente étude était d'évaluer les cultivars de fraisier à différents moments de la récolte sur des critères de qualité des fruits dans un but de sélection des parents potentiels dans des programmes de sélection pour la production de fraises dans les conditions tropicales humides de Datas, au Minas Gerais (Brésil) et dans d'autres régions aux conditions pédo-climatiques similaires. Matériel et méthodes. Les parcelles de fraisiers ont été cultivées sur le domaine de Mape Frutas Farm, situé sur la commune de Datas-MG. Huit cultivars ( Aromas », « Camarosa », «Campinas », « Diamante », «Dover», «Festival», «Oso Grande » et «Toyonaka ») ont été évalués dans un dispositif de split-plot en blocs randomisés. Les données de quatre répétitions sur trois dates de récolte (juin, août et octobre 2012) ont été évaluées. Les fruits des différents cultivars ont été analysés pour leur qualité physico-chimique et leurs propriétés anti-oxydantes. Résultats et discussion. Nous avons relevé une variabilité et une prédominance des facteurs génétiques sur les effets environnementaux pour les paramètres évalués. Les fruits récoltés en fin de cycle de production (octobre) ont présenté les plus fortes teneurs en sucres réducteurs totaux, en vitamine $\mathrm{C}$, en polyphénols, anthocyanes, caroténoïdes, matières solubles, et les plus fortes activités anti-oxydantes totales. Les cultivars Camarosa, Festival, et Toyonoka ont présenté une meilleure qualité des fruits. Conclusion. Sur la base de la dissemblance génétique et de la qualité des fruits, un croisement entre «Toyonoka » et «Camarosa » ou «Festival » nous paraît indiqué pour l'amélioration génétique du fraisier dans la région de Datas et d'autres sites aux conditions pédo-climatiques similaires.
\end{abstract}

Mots clés : Brésil / fraisier / Fragaria $\times$ ananassa / amélioration des plantes / qualité du fruit / critère de sélection / valeur nutritionnelle

\footnotetext{
^ Corresponding author: amandagguimaraes@yahoo.com.br
} 


\section{Introduction}

The strawberry is appreciated in the world for its attractive sensory traits such as intense bright red color, agreeable odor, soft texture, and flavor, which please the consumer [1]. The flavor comes mainly from the balance between sugars and organic acids. The sweetness and acidity are, by standard, measured in ${ }^{\circ}$ Brix and titratable acidity, respectively [2].

The importance of nutritional properties of fruits has increased both in breeding programs and in productive systems $[1,3]$. The strawberry is part of a balanced diet; it is a source of vitamins and minerals essential for a healthy life. The strawberry contains substances with antioxidant properties that are related to reduction of the incidence of chronic diseases, e.g., cardiovascular diseases and certain types of cancer $[1,4,5]$. Among these antioxidants are vitamin $C$ and several phenolic compounds, most of which are represented by flavonoids, mainly anthocyanin and carotenoids $[4,6]$.

The antioxidant activity of fruit has long been considered a mechanism of action in inhibiting mutagenesis and cancer initiation through the ability of eliminating reactive oxygen species and decreasing oxidative DNA damage [7]. The antioxidants depend on the genetic background, and environmental conditions that play an important role in strawberry characteristics, because the content of micronutrients and phytochemicals may greatly vary from cultivar to cultivar and depend on cultural practices $[1,8]$.

In Brazil, strawberry production is distributed across temperate and subtropical regions where it is used both for fresh and industrial consumption [9]. In the city of Datas, Minas Gerais State (Brazil), strawberry farming began in 2005 and has played an important socio-economic role, mainly because of the increased income of small farms and the establishment of workers in rural areas, since much manual labor is required during the harvest season. The climate of this region is classified by the Köppen system as a tropical humid Aw type. Minas Gerais producers have been using protected cultivation to increase production and protection against winds, rain, low temperatures, and pests [10].

Thus, it is important to evaluate genotypes in terms of nutritional properties, as this makes it possible to determine superior individuals for cultivation in this region and in others with similar soil-climatic conditions. Besides, the evaluation of cultivars can indicate possible parents for breeding programs and allow studies that indicate more suitable breeding strategies for this crop $[3,6]$. Some noteworthy examples of such studies are genetic dissimilarity and genetic parameters like the coefficient of genotypic determination, coefficient of genotypic variation, and correlations [11].

The objective of the present study was to analyze cultivars of strawberry at different harvest times with regard to fruit quality aiming to choose the best parents for breeding programs and for cultivation in the tropical conditions of DatasMG, Brazil.

\section{Materials and methods}

\subsection{Plant material}

The stock plants of eight strawberry cultivars ('Aromas', 'Camarosa', 'Campinas', 'Diamante', 'Dover', 'Festival',
'Oso Grande', and 'Toyonoka') were donated by Multiplanta Biotecnologia Vegetal Ltd, a company that develops tissue culture process. Stock plants were multiplied and strawberry cultivars were grown at the Mape Frutas Ltd company, located in Datas-MG (Brazil) (18 $26^{\prime} \mathrm{S}$ latitude, $43^{\circ} 39^{\prime} \mathrm{W}$ longitude, $1,244 \mathrm{~m}$ altitude) where the climate is classified by the Köppen system as a tropical humid Aw type, with a dry season in the winter and rainy season in the summer, and the soil is classified as a Psamment (USS soil taxonomy comparison).

The eight cultivars were evaluated over four replicates. Experimental plots contained 18 plants arranged with $0.30 \times$ $0.30 \mathrm{~m}$ spacing, with a floor area of $2 \mathrm{~m}^{2}$. Planting took place in March 2012 in a protected cultivation system made of low plastic tunnels $(75 \mu \mathrm{m})$ placed $0.80 \mathrm{~m}$ above the beds. The soil bed was also covered with a $30-\mu \mathrm{m}$ white side plastic (mulching) with $0.20 \mathrm{~m}$ height, $0.64 \mathrm{~m}$ length, and $1.00 \mathrm{~m}$ width. Fertigation was applied by the drip irrigation method, and the recommended cultivation treatments for the culture were employed. The fruits were harvested manually, at a maturation stage of 75\%, in June, August, and October 2012, when the average temperatures of every month in the external environment were $14.83,16.75$, and $19.37^{\circ} \mathrm{C}$, respectively.

\subsection{Experimental design}

For the statistical analysis, an experimental randomized block design with a split-plot in time was adopted in which the cultivars were the main plot and the harvest times were the sub-plot. Thus, the following statistical model was considered in the uni- and multi-variate analyses:

$$
Y_{i j k}=m+g_{i}+b_{j}+e_{i j}+c_{k}+g c_{i k}+d_{i j k},
$$

where $Y_{i j k}=$ observation referring to the k-th harvest, of block $\mathrm{j}$, of cultivar $\mathrm{i} ; \mathrm{m}=$ overall mean; $g_{i}=$ effect of the culti$\operatorname{var} \mathrm{i}(\mathrm{i}=1,2, \ldots, \mathrm{I})$ assumed as fixed; $b_{j}=$ effect of block $\mathrm{j}(\mathrm{j}=$ $1,2, \ldots, \mathrm{J})$, assumed as random; $e_{i j}=$ effect of the interaction between cultivar $\mathrm{i}$ and block $\mathrm{j}$, assumed as random (error A); $c_{k}=$ effect of harvest $\mathrm{k}(\mathrm{k}=1,2, \ldots, \mathrm{K})$, assumed as fixed; $g c_{i k}=$ effect of the interaction between cultivar i and the $\mathrm{k}$-th harvest, assumed as fixed; and $d_{i j k}=$ effect of the interaction between the k-th harvest, block j, and cultivar i, assumed as random (error B).

\subsection{Physicochemical analyses}

Analyses were conducted at the Laboratory of Biomass Technology of the Cerrado, at Universidade Federal dos Vales do Jequitinhonha e Mucuri (UFVJM), JK Campus, in Diamantina-MG. Samples, consisting of $100 \mathrm{~g}$ strawberry from each plot of each cultivar, were ground and packed in containers. The following physicochemical analyses were performed:

- Moisture (MTR) was determined by drying at $60{ }^{\circ} \mathrm{C}$ in a vacuum oven until the material reached a constant weight [12]. Results are expressed as \% wet basis. 
- The $\mathrm{pH}$ was measured with a digital $\mathrm{pH}$ meter $(\mathrm{H} / \mathrm{ION}$ METER 450). After the device was calibrated using a buffer solution ( $\mathrm{pH} 4.0$ and 7.0), the electrodes were inserted in the strawberry pulp of each replicate of each treatment [13].

- Soluble solids (SS) were determined by reading on a portable refractometer (QUÍMIS ISSO-9002), 0-32 ${ }^{\circ}$ Brix scale [13]. For the previous calibration of the equipment, a drop of distilled water was deposited into the prism, and the scale was calibrated to zero.

- Titratable acidity (TA) was determined by titrating the sample and results were expressed as g citric acid $100 \mathrm{~g}^{-1}$ fresh fruit of strawberry (FW) [13].

- Soluble pectin (SP) content was determined by the technique described by Cready and Comb [14]. Calorimetric determination was performed via carbazole reaction, following the technique described by Bitter and Muir [15]. Results were expressed as mg galacturonic acid $100 \mathrm{~g}^{-1}$.

- The total reducing sugars (TRS) were extracted and measured by the Somogyi-Nelson method, described by Maldonade et al. [16]. The data was read on a spectrophotometer (Shimadzu ${ }^{\circledR}$ UV MINI 1240), and the obtained results were expressed as $\mathrm{g} 100 \mathrm{~g}^{-1}$.

\subsection{Antioxidant measurements}

The following analyses of antioxidants were performed:

- Carotenoids (CAR) were evaluated using an isopropyl alcohol:hexane (3:1) extraction solution according to AOAC [12]. Results were expressed as $\mu \mathrm{g} \beta$-carotene $\mathrm{g}^{-1}$.

- Vitamin C (VTC) content was determined by the colorimetric method based on reduction of 2,6-dichlorophenol indophenol sodium salt dye by an acidic solution of ascorbic acid, in which, at end of the reaction, ascorbic acid turns into its oxidized form (dehydroascorbic acid), quantified in this form [12]. Results were expressed as mg ascorbic acid $100 \mathrm{~g}^{-1}$.

- Phenolic compounds (PHN) were extracted according to Zielinski and Kozlowska [17], and assayed by the Folin-Denis method, using the calibration curve of tannic acid. Results were expressed as mg tannic acid $100 \mathrm{~g}^{-1}$.

- Anthocyanins (ANT) were evaluated by the $\mathrm{pH}$ differential method described by Lee et al. [18], in which the sample was diluted into two distinct $\mathrm{pH}$, as follows: $\mathrm{pH} 1.0$ (chloride buffer $0.025 \mathrm{~mol} \mathrm{~L}^{-1}$ ) and $\mathrm{pH} 4.5$ (acetate buffer $0.4 \mathrm{~mol} \mathrm{~L}^{-1}$ ). The sample was read on a spectrophotometer (Shimadzu ${ }^{\circledR}$ UV MINI 1240) at two wavelengths (510 nm and $700 \mathrm{~nm}$ ), and results were expressed as cyanidin-3glucoside $\mathrm{mgL}^{-1}$.

- Flavonoids (FLA) were quantified using the same extract as that of phenols and quantified by spectrophotometry (Shimadzu ${ }^{\circledR}$ UV MINI 1240), using the calibration curve of pyrocatechol, and quantified according to Zhishen et al. [19]. Results were expressed as mg pyrocatechol $100 \mathrm{~g}^{-1}$.

- Total antioxidant activity (TAA) was determined by the iron reduction method described by Firuzi et al. [20]. The antioxidant compounds of the sample were extracted in $80 \%$ methanol and subsequently $70 \%$ acetone; the final volume of the extract was $100 \mathrm{~mL}$. Results were expressed as $\mu \mathrm{M}$ ferrous sulfate $\mathrm{g}^{-1}$.

After the analysis of variance, when significance was identified at $5 \%$ probability $(P<0.05)$ by the $F$-test for the effects of cultivar, harvest, and interaction (cultivar $\times$ harvest), means were compared by Tukey's test. In the multivariate statistical analysis, generalized Mahalanobis distance was estimated for the application of Tocher's optimization-clustering method. For better visualization of the existing dissimilarity among the accessions, the first two canonical variables and the hierarchical dendrogram were represented graphically by the UPGMA (Unweighted Pair Group Method with Arithmetic Mean) method. The uni- and multivariate analyses were performed using GENES genetic-statistical software [21].

\section{Results and discussion}

\subsection{Overall variability observed}

The variability among cultivars was found significant for all evaluated traits $(P<0.05)$ (table $I)$. The source of variation harvest time had a significant effect on most traits, e.g. $\mathrm{pH}$, soluble solids (SS), titratable acidity (TA), soluble pectin content, total reducing sugar, carotenoids, vitamin $\mathrm{C}$ content, anthocyanins, phenols, and total antioxidant activity. The total antioxidant capacity is indicative of total vitamin $\mathrm{C}$ and phenolic compounds, most of which are represented by flavonoids, mainly the anthocyanins [4]. Only the traits moisture and flavonoids were not significant for harvest time as factor of variation. There was no interaction between harvest time and cultivars only for the traits soluble solids and total antioxidant activity, indicating that for these two traits, the cultivars responded similarly, regardless of the time of harvest.

All traits showed high precision in the evaluation, with a genotypic coefficient of determination $\left(\mathrm{H}^{2}\right)$ greater than $80 \%$ (table I). This can be explained by the evaluation at the laboratory, when the measurement errors are small, so the residual variation is lower. $\mathrm{H}^{2}$ expresses the reliability on the phenotypic value as a guide for the genetic value [11]. The traits with the highest genotypic coefficient of variation (GCV) were carotenoids, phenols, anthocyanins, vitamin C, and flavonoids (table I). GCV expresses the amount of existing genetic variation; thus, high estimates are desirable in breeding programs, aiming to allow the selection of genotypes of superior quality over the preexisting genotypes.

The moisture trait had a high and negative correlation $\left(R^{2}<-0.8\right)$ with the SS, SS:TA ratio, total reducing sugars, and vitamin C traits (table I). According to Jacques et al. [22], moisture may be correlated negatively with SS and total reducing sugars due to the concentration of sugars, which is inversely proportional to the moisture content. The SS, however, had a high and positive correlation $\left(R^{2}>0.78\right)$ with the SS:TA ratio, total reducing sugars, vitamin $\mathrm{C}$, carotenoids, and total antioxidant activity. The positive correlation between soluble solids and total reducing sugars can be explained by the representation of the soluble solids in the total sugars [23]. High and positive correlations $\left(R^{2}>0.8\right)$ were also observed for some 


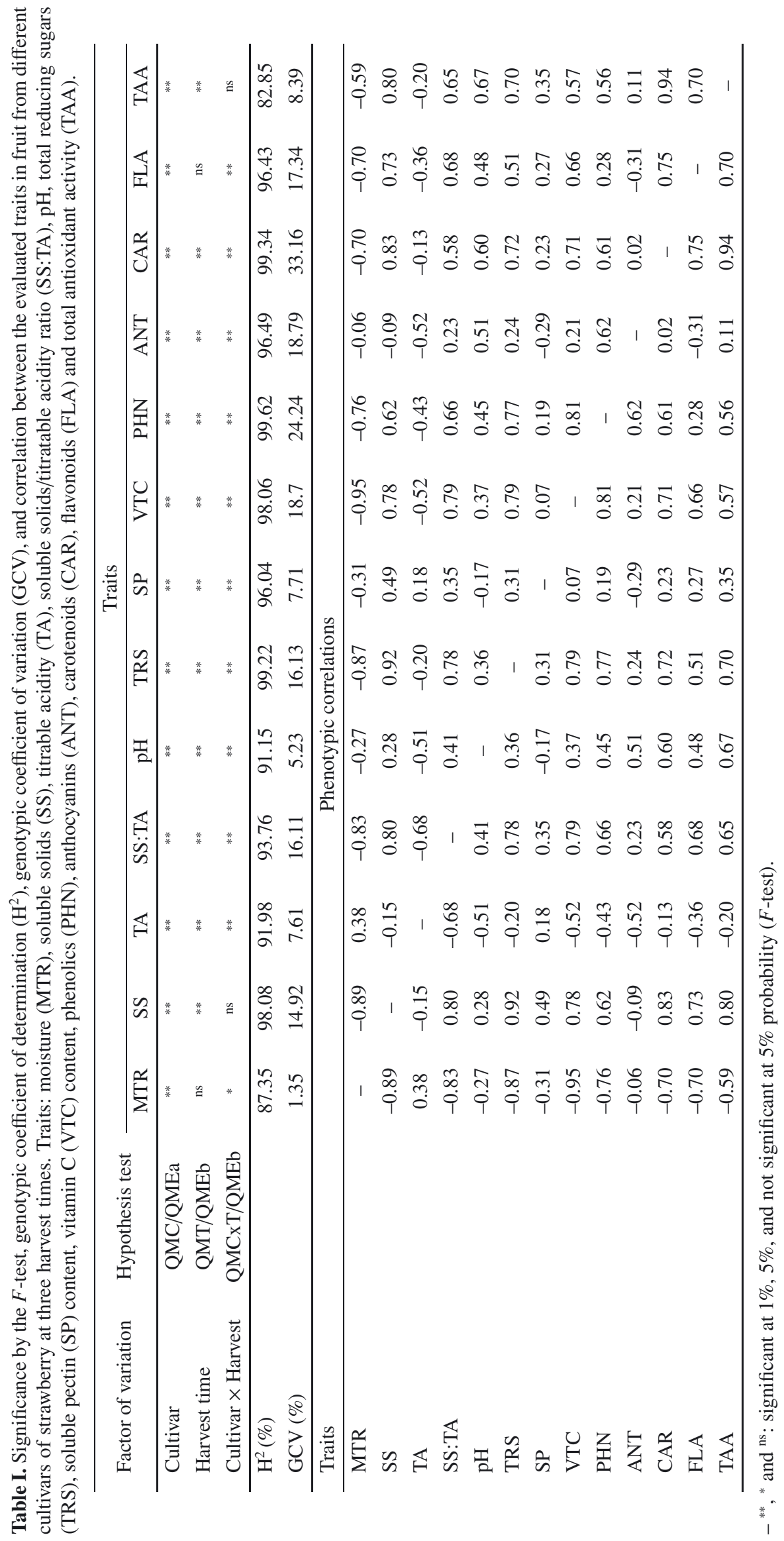


analyses of antioxidant character, e.g., vitamin C with phenols, and carotenoids with total antioxidant activity, since vitamin $\mathrm{C}$ is one of the main factors responsible for the antioxidant activity, as also are the phenolic compounds [24].

Surprisingly, the correlation between the total antioxidant activity (TAA) and anthocyanins (ANT) was low, as ANT contributed to TAA [4]. This may be explained by the fact that these two traits behave in an opposite manner, with regard to fruit maturation. The anthocyanin content is accumulated in the fruit red stage, whereas the antioxidant capacity may vary during the maturation stage; in the majority of cases, green fruits have higher levels of this component than ripe fruits [3]. The study of the existing associations between the traits is important, as it allows for inferences on the consequence that selection for one trait may have on the others, and also indicates the viability of indirect selection when the trait of main interest is hard to measure or has a low heritability.

\subsection{Variability due to harvesting times}

The trait moisture was not significantly affected by the source of variation time of harvest (table II), averaging $89.80 \%$. Moisture is related to the stability, quality, and composition of the fruit [22]. In a work with different strawberry cultivars in the same region in the 2010 crop [10], an average moisture value slightly higher than those of the present study were found: $92.70 \%$. In the current study, the cultivars whose fruits showed the highest average moistures were 'Aromas' (91.10\%), 'Diamante' (91.29\%), and 'Dover' (91.36\%), differing from cvs Toyonoka and Campinas. Moisture contents obtained in our study corroborate those found in different cultivars in the region of Atibaia-SP by Pinto et al. [25], who observed higher values for cvs Camarosa (91\%), Dover $(89 \%)$, and Oso Grande (90.6\%), but a similar moisture content $(87.9 \%)$ in the $\mathrm{cv}$. Toyonoka.

The $\mathrm{pH}$ has a great importance in the physicochemical, biological, and sensory traits and, together with titratable acidity, it is one of the most important properties in the acid balance of wine [26]. The strawberries harvested in June and August showed the highest $\mathrm{pH}$ levels: 3.27 and 3.38, respectively. 'Camarosa' had the highest average $\mathrm{pH}$ value, 3.39, and in the study of Guimarães et al. [10] in Datas-MG, the 2011 harvest for cv. Camarosa had slightly larger $\mathrm{pH}$ values (3.49). These different values in same regions may be related to physiological factors and to soil-climatic conditions such as temperature and precipitation $[1,8]$.

Regarding acidity, cv. 'Aromas' and 'Diamante' produced more acid fruit $\left(0.67 \mathrm{~g}\right.$ citric acid $\left.100 \mathrm{~g}^{-1}\right)$. The acidity due to organic acids is an important characteristic as regards taste and aroma of many fruits [27]. Fruits were more acid in October $\left(0.69 \mathrm{~g}\right.$ citric acid $\left.100 \mathrm{~g}^{-1}\right)$. In the experiments of Mangarim et al. [28], with cv. Camarosa, in Pelotas-RS, the authors found acidity values similar to those in the present experiment with the same cultivar: $0.60 \mathrm{~g}$ citric acid $100 \mathrm{~g}^{-1}$. Soluble solids (SS) are one of the attributes of quality in terms of flavor, as it indicates the amount of sugars present in the fruit [29]. 'Toyonoka' had fruits with the highest soluble solid content $\left(8.68^{\circ}\right.$ Brix $)$; this cultivar also showed the lowest amount of water, which might have led to a greater concentration of soluble solids. In the comparison of means of the harvest times, the results showed that when the fruit was collected in the hotter months (August and October), there was an elevation in SS. Several factors may influence SS, varying between species, cultivars, maturation stages, and climate [27]. The highest SS:TA ratio was observed in August (15.09), as that was the month in which fruits were most acid (0.47), causing the SS:TA ratio to be higher, since they are inversely proportional. The cultivars that showed the best ratio, on average, were: 'Toyonoka' (13.79) and 'Festival' (13.94), not differing from 'Camarosa' (13.43) and 'Campinas' (12.65). When this ratio is too low, the product loses quality [27].

The total reducing sugars are among the main soluble components of strawberry, and they work as sources of energy for metabolic transformations [27]. The cultivars that showed the greatest amounts of total reducing sugars were 'Toyonoka' (6.84 g $\left.100 \mathrm{~g} \mathrm{~g}^{-1}\right)$, 'Festival' (6.52 g $100 \mathrm{~g} \mathrm{~g}^{-1}$ ), and 'Camarosa'

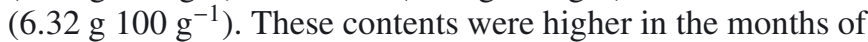

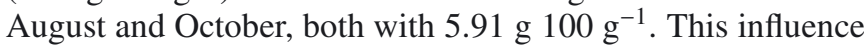
may be a result of the increase in temperature and light intensity, which favor the accumulation of sugar in the fruit. The soluble pectin is a polysaccharide resulting from the partial hydrolysis of the insoluble protopectin that constitutes the cell wall, and it is responsible for changes in texture of fruit and vegetables [30]. The highest values for soluble pectin content were found in 'Toyonoka', 'Dover' and 'Campinas', indicating less firmness of the fruit as compared with cvs Camarosa, Diamante, Festival, and Oso Grande. This reduced firmness may be the result of transformations that take place during fruit ripening, which releases calcium and solubilizes the protopectin of the cell walls via enzymatic activity, leading to loss of firmness, thus adversely affecting their postharvest preservation [27].

In the comparison of harvest times, the fruits harvested in October had greater levels of vitamin C, phenols, anthocyanins, and carotenoids (table III), possibly as a result of the temperature increase [8]. Vitamin C is important in the development and regeneration of muscles, teeth, and bones, and in the formation of collagen, besides antioxidant benefits that reduce the risk of cardiovascular and pulmonary disease [30]. The greatest contents of vitamin C (mg ascorbic acid $100 \mathrm{~g}^{-1}$ ) were found in 'Camarosa' (76.36), 'Campinas' (75.95), 'Festival' (76.69), 'Oso Grande' (79.39), and 'Toyonoka' (83.77). In a study conducted in Lavras-MG with different strawberry cultivars [32], similar values were found for cv. Camarosa and lower values for cv. Toyonoka.

\subsection{Variability in antioxidant compounds}

Phenols play an important role in the processes of inhibition of risk of cardiovascular diseases, and they can work on the oxidative stress related to several chronic-degenerative pathologies such as diabetes, cancer, and inflammatory processes [33]. 'Camarosa' (243.63 mg tannic acid $100 \mathrm{~g}^{-1}$ ) had a higher PHN content, but did not differ from 'Campinas' (230.89 mg tannic acid $100 \mathrm{~g}^{-1}$ ) and 'Festival' (231.64 mg tannic acid $\left.100 \mathrm{~g}^{-1}\right)$. The fruits harvested in October displayed 


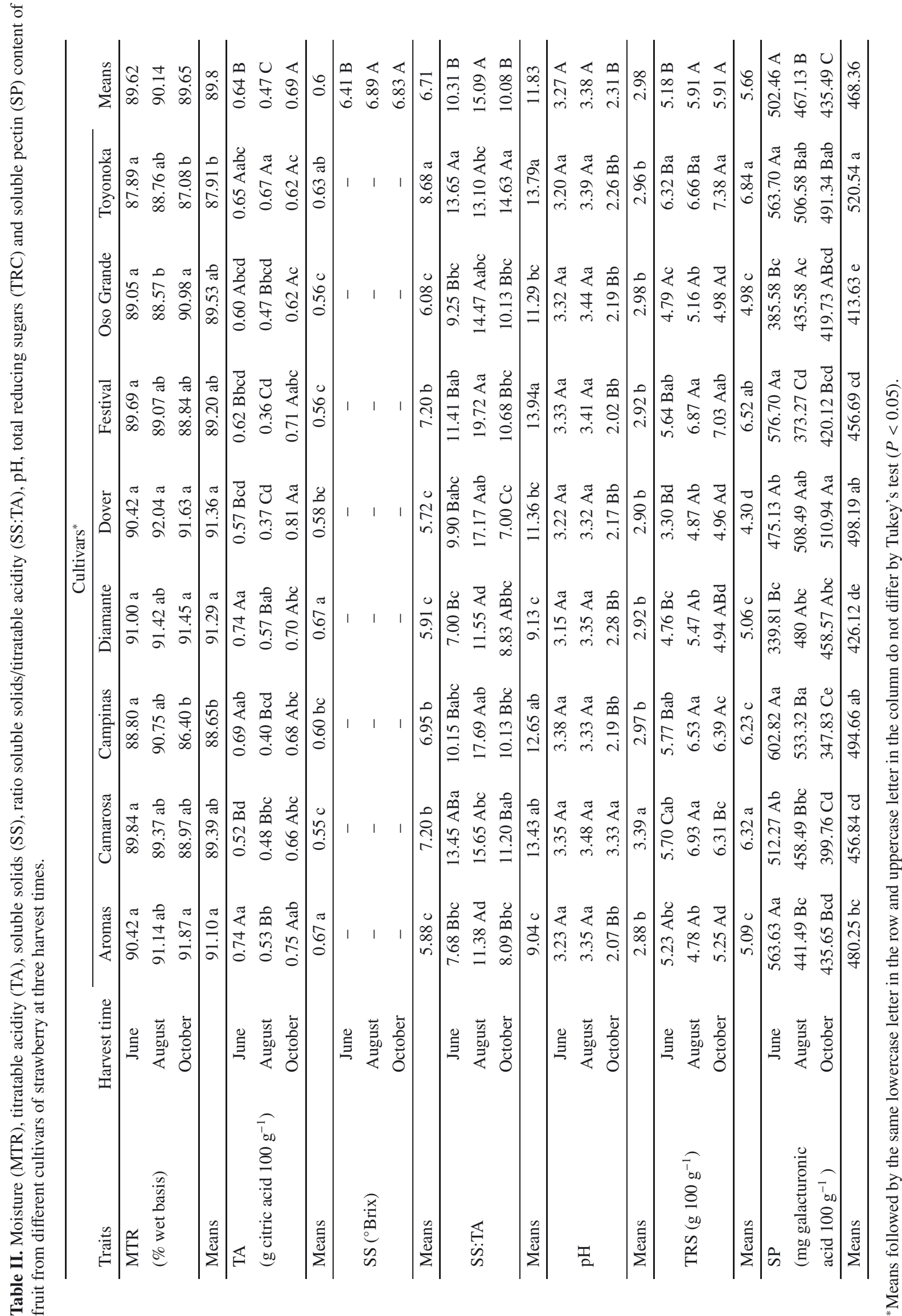




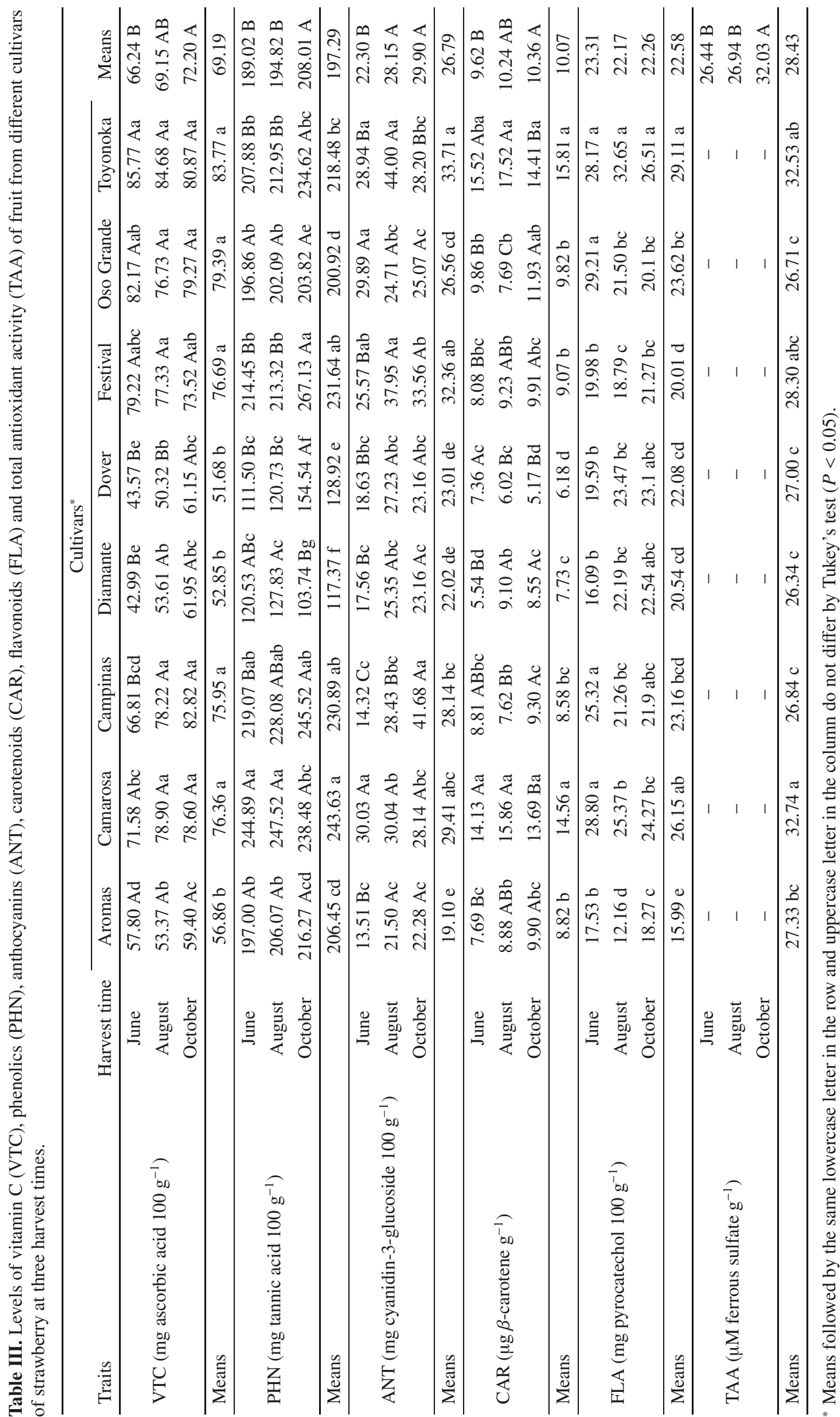




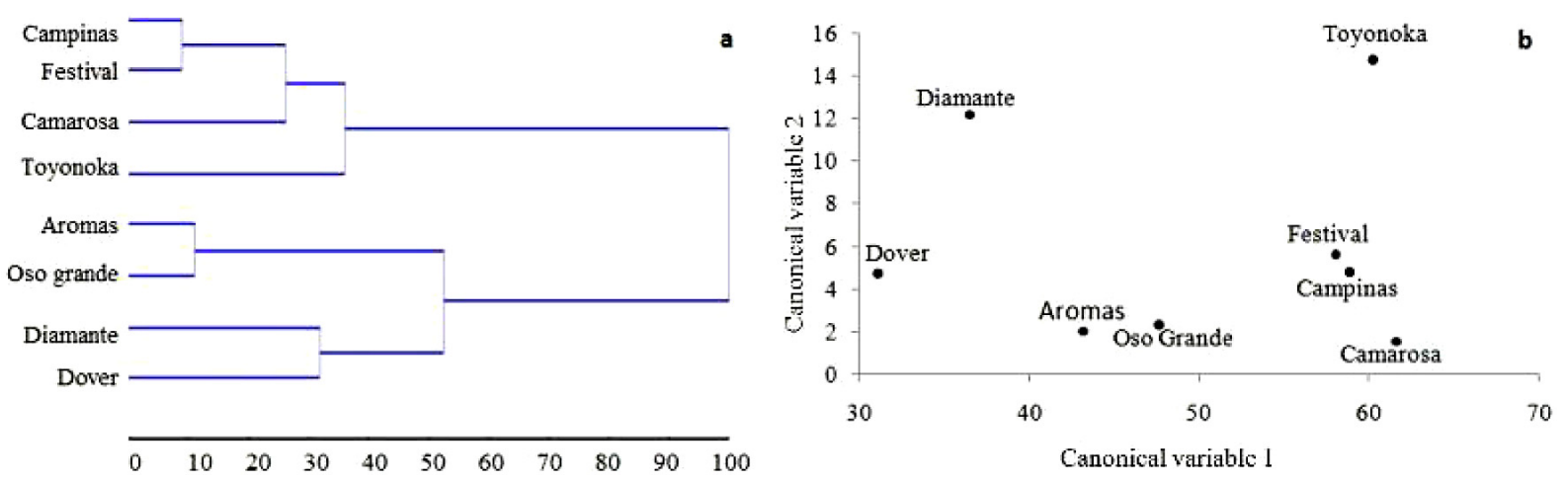

Figure 1. Dendrogram illustrating the dissimilarity pattern obtained by UPGMA's method, (a) based on Mahalanobis distance and, (b) graphic dispersion of scores relative to the first two canonical variables for eight cultivars of strawberry.

higher values for phenolic compounds, which may be related to the temperature increase [1,8]. Rocha et al. [32], in experiments conducted in Lavras-MG with 'Toyonoka', found values near those found in this study for phenol compounds: $217.14 \mathrm{mg}$ tannic acid $100 \mathrm{~g}^{-1}$.

In addition to playing a part in fruit color, anthocyanin pigments have antioxidant properties which participate in the prevention of hyperglycemia and reduction of risk of cardiovascular disease. Studies also indicate that they can inhibit the proliferation of cancer cells [34]. The cultivar that showed the greatest content of anthocyanin was Toyonoka (33.71 mg cyanidin-3-glucoside $100 \mathrm{~g}^{-1}$ ), not differing from cvs Festival (32.36 mg cyanidin-3-glucoside $100 \mathrm{~g}^{-1}$ ) and Camarosa (29.41 mg cyanidin-3-glucoside $100 \mathrm{~g}^{-1}$ ) (table III). In studies conducted in Bordignon Junior et al. [35] found close values for anthocyanins in the cv. Camarosa at $\mathrm{pH} 7$ : $22.16 \mathrm{mg}$ cyanidin-3-glucoside $100 \mathrm{~g}^{-1}$. In addition to promoting the activity of provitamin A, carotenoids develop other activities in the physiological system and are associated with protection against chronic-degenerative diseases [36]. Cultivars Toyonoka and Camarosa contained the highest amount of carotenoids: 15.81 and $14.56 \mu \mathrm{g} \beta$-carotene $\mathrm{g}^{-1}$, respectively. Severo et al. [37], in experiments with cultivar Aromas, originating from Flores da Cunha-RS, found lower mean carotenoid contents than the present study with the same cultivar: $6 \mu \mathrm{g}$ B-carotene $\mathrm{g}^{-1}$.

Flavonoids have antioxidant activity; antimicrobial, antiallergic, and antihypertensive properties; and can inhibit the activities of some physiologic enzymes and receptors [38]. No differences were observed between the harvest times for flavonoids which averaged $22.58 \mathrm{mg}$ pyrocatechol $100 \mathrm{~g}^{-1}$ ( $\mathrm{ta}$ ble III). In a work with different strawberry cultivars in the same region in the 2010 crop, [10] obtained a lower average flavonoid content $\left(15.81 \mathrm{mg}\right.$ pyrocatechol $\left.100 \mathrm{~g}^{-1}\right)$ than that found in the present study. The cultivar with the highest level was 'Toyonoka' (29.11 mg pyrocatechol $100 \mathrm{~g}^{-1}$ ), which did not differ from 'Camarosa' (26.15 mg pyrocatechol $100 \mathrm{~g}^{-1}$ ). For total antioxidant activity, 'Camarosa' presented the highest value $\left(32.74 \mu \mathrm{M}\right.$ ferrous sulfate $\left.\mathrm{g}^{-1}\right)$ but did not differ from 'Toyonoka' ( $32.53 \mu \mathrm{M}$ ferrous sulfate $\left.\mathrm{g}^{-1}\right)$ and 'Festival' $\left(28.30 \mu \mathrm{M}\right.$ ferrous sulfate $\left.\mathrm{g}^{-1}\right)$. Pineli et al. [39] conducted a study with cv. Oso Grande in Brazilândia-DF and obtained higher antioxidant levels with the same cultivar $(34.30 \mu \mathrm{M}$ ferrous sulfate $\mathrm{g}^{-1}$ ) as in the present study. In the comparison of harvest periods, October had the highest antioxidant activity ( $32.03 \mu \mathrm{M}$ ferrous sulfate $\mathrm{g}^{-1}$ ), which may be due to the higher temperatures in that month [40].

\subsection{Genetic dissimilarity between cultivars}

In the multivariate analysis, four groups were formed by Tocher's clustering method: the first comprised the cvs Campinas, Festival and Camarosa; the second contained the cvs Aromas and Oso Grande; the third, the cvs Diamante and Dover; and the last group was formed by 'Toyonoka'. In the dendrogram (figure 1a), this same clustering trend was observed when considering a cutoff of $35 \%$. The first group comprised cultivars with similar results for the traits SS, SS:TA, vitamin $\mathrm{C}$, anthocyanins, and phenols. The second included cultivars with close results for phenols and carotenoids. The third group, which had a greater combination of antioxidant properties (vitamin C, phenolic, anthocyanins, carotenoids and flavonoids), had a greater contribution. The last group, formed by a single cultivar, differed from the others mainly in the traits total pectin and soluble solids.

The graphic dispersion of the scores of the first two canonical variables (figure $1 b$ ) also demonstrates that these same four clusters can be formed, but it is more visible than 'Diamante' and 'Dover', despite being part of the same group, show greater dissimilarity between each other, indicating greater intra-group distance. According to Azevedo et al. [11], it is important to compare the results of several multivariate analysis techniques, which makes it possible to better evaluate the divergence, thus allowing for a more precise interpretation of results. Also according to these authors, in addition to considering the performance of cultivars per se, genetic diversity should be taken into account in the selection of parents for breeding programs, thereby providing a higher mean and greater variability of the progenies.

Thus, based on fruit quality and genetic dissimilarity, the crossing between 'Toyonoka' and 'Camarosa' or 'Festival' may enable the generation of progenies with desirable quality and high genetic variability. In the studies of Guimarães et al. [41], at this same time of the year and region, these cultivars were evaluated as to agronomic traits, and it was 
found that cvs Camarosa and Festival were the most productive, demonstrating their importance as parents in breeding programs.

\section{Conclusion}

The present study showed a clear genetic variability and a predominance of genetic factors over environmental effects for the traits assessed in strawberry grown in the state of Minas Gerais, Brazil. The strawberry harvested at the end of the crop cycle (October) produced the greatest amounts of total reducing sugars, vitamin $\mathrm{C}$, phenols, anthocyanins, carotenoids, soluble solids, and total antioxidant activity. The cultivars Camarosa, Festival, and Toyonoka had the best fruit quality. These performances indicate the cross between 'Toyonoka' and 'Camarosa' or 'Festival' for the genetic breeding of strawberry for cultivation in the city of Datas-MG, Brazil, and in other regions with similar soil-climatic conditions.

Acknowledgements. The Multiplanta Biotecnologia Vegetal Ltd company is acknowledged for donating the strawberry parents. The authors are thankful to the Mape Frutas Ltd company for the experimental area and for donating the strawberry fruit for the development of the project. CNPq, FAPEMIG, and Capes are gratefully acknowledged for the fellowship and resources provided for the development of the project.

\section{References}

[1] Battino M., Beekwilder J., Denoves-Rothan B., Laimer M., McDougall G.J., Mezzetti B. Bioactive compounds in berries relevant to human health, Nutr. Rev. 67 (2009) S145-S150.

[2] Cordenunsi B.R., Nascimento J.R.O., Genovese M.I., Lajolo F.M. Influence of cultivar on quality parameters and chemical composition of strawberry fruits grown in Brazil, J. Agric. Food. Chem. 50 (2002) 2581-2586.

[3] Tulipani S., Marzaban G., Herndl A., Laimer M., Mezzetti B., Battino M. Influence of environmental and genetic factors on health-related compounds in strawberry, Food Chem. 124 (2011) 906-913.

[4] Giampieri F., Tulipani S., Alvarez-Suarez J.M., Qulies J.L., Mezzetti B., Battino M. The strawberry: Composition, nutritional quality, and impact on human health, Nutrition 28 (2012) 9-19.

[5] Lal S., Ahmed N., Singh S.R., Singh D.B., Sharma O.C., Kumar R., Variability of health and bioactive compounds in strawberry (Fragaria $\times$ ananassa Duch.) cultivars grown under an Indian temperate ecosystem, Fruits 68 (2013) 423-434.

[6] Atkinson C.J., Dodds P.A.A., Ford Y.Y., Le Mière J., Taylor J.M., Blake P.S., Paul N. Effects of cultivar, fruit number and reflected photosynthetically active radiation on Fragaria $\times$ ananassa Duch. productivity and fruit ellagic acid and ascorbic acid concentrations, Ann. Bot. 97 (2006) 429-441.

[7] Stoner G.D., Wang L.S., Casto B.C. Laboratory and clinical studies of cancer chemoprevention by antioxidants in berries, Carcinogenesis 29 (2008) 1665-74.

[8] Tulipani S., Mezzetti B., Capocasa F., Bompadre S., Beekwilder J., Ric de Vos C.H., et al. Antioxidants, phenolic compounds, and nutritional quality of different strawberry genotypes, J. Agric. Food. Chem. 56 (2008) 696-704.
[9] Radin B., Lisboa B.B., Witter S., Barni V., Reisser Junior C., Matzenauer R., Fermino MH. Desempenho de quatro cultivares de morangueiro em duas regiões ecoclimáticas do Rio Grande do Sul, Hortic. Bras. 29 (2011) 287-291.

[10] Guimarães A.G., Vieira G., Batista A.G., Pinto N.A.V.D., Viana D.J.V., Características físico-químicas e antioxidantes de cultivares de morangueiro no Vale do Jequitinhonha, Tecnol. Ciênc. Agro. 7 (2013) 35-40.

[11] Azevedo A.M., Andrade Júnior V.C., Oliveira C.M., Fernandes J.F.C., Pedrosa C.E., Dornas M.F.S., Castro B.M.C., Seleção de genótipos de alface para cultivo protegido: divergência genética e importância de caracteres, Hortic. Bras. 31 (2013) 260-265.

[12] AOAC, Association of Official Analytical Chemistry (AOAC). Official Methods of Anaysis of the AOAC, Washington, United States of America, 2012.

[13] IAL. Instituto Adolfo Lutz (IAL), Métodos Físico-Químicos para Análise de Alimentos. São Paulo, Brasil, 2008.

[14] Cready R.M.M., Comb E.A.M., Pectic constituents in ripe and unripe fruit, Food Res. 19 (1952) 530-533.

[15] Bitter V., MUIR H.M.A., Modified uronic acid carbazole reaction, Anal. Biochem. 4 (1962) 330-334.

[16] Maldonade I.R., Carvalho P.G.B., Ferreira N.A., Moulin B.S.F., Protocolo para determinação de açúcares redutores pelo método de Somogyi-Nelson, Comunicado Técnico. 86 (2013) 1-4.

[17] Zielinski H., Kozlowska H., Antioxidant activity and total phenolics in selected cereal grains and their different morphological fractions, J. Agric. Food Chem. 48 (2000) 2008-2016.

[18] Lee J., Durst R.W., Wrolstad R.E., Determination of total monomeric anthocyanin pigment content of fruit juices, beverages, natural colorants, and wines by the $\mathrm{pH}$ differential method: collaborative study, J. AOAC Intern. 88 (2005) 1269-1278.

[19] Zhishen J., Mengcheng T., Jianming W., The determination of flavonoid contents in mulberry and the scavenging effects on superoxide radicals, Food Chem. 64 (1999) 555-559.

[20] Firuzi O., Lacanna A., Petrucci R., Marrosu G., Saso L., Evaluation of the antioxidant activity of flavonoids by "ferric reducing antioxidant power" assay and cyclic voltammetry, Biochim. Biophy. Acta 1721 (2005) 174-184.

[21] Cruz C.D., Genes - a software package for analysis in experimental statistics and quantitative genetics, Acta Sci. 35 (2013) 271-276.

[22] Jacques A.C., Pertuzatti T.B., Barcia M.T., Zambiazi R.C., Doce em massa de amora preta (Rubus spp): análise sensorial e de fitoquímicos, Aliment. Nutri. 20 (2009) 625-632.

[23] Magro N.G.D., Coelho S.R., Haida K.S., Berté S.D., Moraes S.S., Comparação físico-química de frutos congelados de Butia eriospatha (Mart.) Becc. do Paraná e Santa Catarina-Brasil, Rev. Varia Scien. 6 (2006) 33-42.

[24] Everette J.D., Bryant Q.M., Green A.M., Abbey Y.A., Wangila G.W., Walker R.B., Thorough study of reactivity of various compound classes toward the Folin-Ciocalteou reagent, J. Agric. Food Chem. 58 (2010) 139-144.

[25] Pinto M.S., Lajolo F.M., Genovese M.I. Bioactive compounds and quantification of total ellagic acid in strawberries (Fragaria $\times$ ananassa Duch.). Food Chem. 107 (2008) 1629-1635.

[26] Daudt C.E., Fogaca A.O., Efeito do ácido tartárico nos valores de potássio, acidez titulável e $\mathrm{pH}$ durante a vinificação de uvas Cabernet Sauvignon, Ciênc. Rur. 38 (2008) 2345-2350.

[27] Chitarra M.I.F., CHITARRA A.B., Pós-colheita de frutos e hortaliças: Fisiologia e Manuseio, Lavras, Brasil, 2005.

[28] Mangarim M.B., Cantilliano R.F.F., Coutinho E.F., Sistemas e condições de colheita e armazenamento na qualidade de morangos cv. Camarosa, Rev. Bras. Frutic. 28 (2006) 185-189. 
[29] Portela I.P., Peil R.N., Rodrigues S., Carini F., Densidade de plantio, crescimento, produtividade e qualidade das frutas de morangueiro "Camino Real" em hidroponia, Rev. Bras. Frutic. 34 (2012) 792-798.

[30] Mesbahi G., Jamalian J., Farahnaky A. A comparative study on functional properties of beet and citrus pectins in food systems. Food Hydrocolloid. 19 (2005) 731-738.

[31] Bree V., Baetens J., Samapundo S., Devlieghere F., Laleman R., Vandekinderen I., No-seda B., Xhaferi R., De Baets B., De Neulenaer B. Modelling the degradation kinetics of vitamin $\mathrm{C}$ in fruit juice in relation to the initial headspace oxygen concentration, Food Chem. 134 (2012) 207-214.

[32] Rocha D.A., Abreu C.M.P., Corrêa A.D., Santos C.D., Fonseca E.W.N., Análise comparativa de nutrientes funcionais em morangos de diferentes cultivares da região de Lavras-MG, Rev. Bras. Frutic. 30 (2008) 1124-1128.

[33] Graf B.A., Milbury P.E., Blumberg J.B. Flavonols, flavonones, flavanones and human health: Epidemological evidence, J. Med. Food. 8 (2005) 281-290.

[34] Patras A., Brunton N.P., O'donnell C., TiwarI B.K., Effect of thermal processing on anthocyanin stability in foods; mechanisms and kinetics of degradation, Trends Food Sci. Tecnol. 21 (2010) 3-11.

[35] Bordignon Junior C.L.V., Francescatto A.A., Nienow E., Calvete F., Reginatto H., Influência do pH da solução extrativa no teor de antocianinas em frutos de morango. Ciênc.Tecnol. Aliment. 29 (2009) 183-188.
[36] Maiani, G., Periago Castón M.J., Catasta G., Toti E., Cambrodón I.G., Bysted A., Granado-Lorencio F., OlmedillaAlonso B., Knuthsen P., Valoti M., Böhm V , Mayer-Miebach E., Behsnilian D., Schlemmer U. Carotenoids: actual knowledge on food sources, intakes, stability and bioavailability and their protective role in humans, Mol. Nutr. Food Res. 53 (2009) S194-S218.

[37] Severo J., Tiecher A., Santos R.S., Silva J.A., Rombaldi C.V., Irradiação gama na qualidade pos-colheita e atividade antioxidante de morangos cv. Camarosa, Rev. Magistra. 26 (2013) 1906-1910.

[38] Santos-Buelga C., Scalbert A. Proanthocyanidins and tanninlike compounds - nature, occurrence, dietary intake and effects on nutrition and health. J. Sci. Food Agric. 80 (2000) 1094-117.

[39] Pineli L.L.O., Moretti C.L., Santos M.S., Campos A.B., Brasileiro A.V., Córdova A.C., Chiarello M.D., Antioxidants and other chemical and physical characteristics of two strawberry cultivars at different ripeness stages, J. Food Compos. Anal. 24 (2011) 11-16.

[40] Merzlyak M.N., Solovchenko A.E., Smagin A.I., Gitelson A.A. Apple flavonols during fruit adaptation to solar radiation: spectral features and technique for non-destructive assessment, J. Plant Physiol. 162 (2005) 151-160.

[41] Guimarães A.G., Andrade Junior V.C., Elsayed A.Y.A.M., Fernandes J.S.C., Ferreira M.A.M., Potencial produtivo de cultivares de morangueiro, Rev. Bras. Frutic. 37 (2015) 106-114.

Cite this article as: Amanda Goncalves Guimarães, Valter Carvalho Andrade Júnior, Alcinei Mistico Azevedo, Tiago Jesus Guedes, Nísia Andrade Villela Dessimoni Pinto. Quality of strawberry grown in Brazilian tropical humid conditions for breeding programs. Fruits 71 (2016) 151-160. 